\title{
Design and analysis of controllers for high voltage gain DC-DC converter for PV panel
}

\author{
S. Nagaraj ${ }^{1}$, R. Ranihemamalini' ${ }^{2}$ L. Rajaji ${ }^{3}$ \\ 1,2 Department of Electrical and Electronics Engineering, St. Peter's Institute of Higher Education and Research, India \\ ${ }^{3}$ Department of Electrical and Electronics Engineering, ARM, College of Engineering and Technology, India
}

\begin{tabular}{l}
\hline Article Info \\
\hline Article history: \\
Received Sep 9, 2019 \\
Revised Nov 8, 2019 \\
Accepted Dec 17, 2019 \\
\hline
\end{tabular}

Keywords:

Boost converter

Fuzzy logic controller

High voltage gain

Pv panel

Steady state analysis

\begin{abstract}
Bidirectional high gain DC-DC buck boost converter is a virtual interface among PV source and inverter fed motor drive. In this article, a PV panel integrating a non-isolated bidirectional DC/DC converter that has high voltage gain voltage and a 3 phase three level DC/AC inverter is projected. It highlights the comparison between proportional integral controller (PIC), fractional order proportional integral derivative Controller (FOPIDC) and fuzzy logic controller (FLC) based Bidirectional DC/DC Power Converter System (BDDPCS). The design, model and simulation using SIMULINK of open loop BDDPCS and closed loop PIC, FOPIDC and FLC based BDDPCS are done and the results are discussed. The findings indicate higher performance for FLC based control of BDDPCS. The proposed BDDPCS has merits such as bidirectional power transferability, lesser hardware count with enhanced dynamic response. The hardware of BDDPCS is tested and the experiment result is compared in association with simulation results.
\end{abstract}

This is an open access article under the CC BY-SA license.

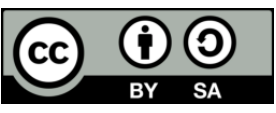

\section{Corresponding Author:}

S. Nagaraj,

Research Scholar, Department of Electrical and Electronics Engineering,

St. Peter's Institute of Higher Education and Research,

Tonakela Camp Road, Sankar Nagar, Avadi, Chennai, Tamil Nadu 600054, India.

Email: nagarajsubramani11@gmail.com

\section{INTRODUCTION}

Solar panels are gathering more popularity among the growing environment because of pollution free nature and overcoming of difficulty in depletion of fuels [1]. Usually, PV cells are connected in series to provide high voltage (HV) essential for electric motor drives. However, the variation in temperature gradient and charging imbalance between the cells may lead to deprivation of solar cell life span [2,3]. Bidirectional DC/DC buck boost isolated power converters such as half bridge and full bridge deliver a better gain in voltage during stepping up as well as stepping down by doing adjustments on transformers turns ratio but occurrence of leakage reactance on the transformer coupling might lead to a hazardous HV sparks in switches at switching transients, huge CU loss and not much suitable for larger variation of voltages $[4,5]$. Soft switch innovation on converters created a better way for decreasing the switching losses during transients [6, 7]. On a other hand, the number of operating switches increases which leads to the increase in conduction losses, complexity and cost [8]. Switched capacitor (SC) based DC/DC converter could promise for a reduction in size of power converter and possess better power density. Still high gain in voltage is necessary which lead to increase in the size of the SC $[9,10]$. On the other end, switched inductor (SL) can handle large voltage gain no matter on which quadrant it is operated [11].

Hence, DC-DC power converter that has high voltage gain has yield many researchers attention. This article attempts to recognize a better bidirectional DC/DC converter topology for solar panel fed 
induction motor with high gain in voltage $[12,13]$. First, the existing and the proposed DC-DC bidirectional converter would be discussed. It elaborates, which topology can offer high power output. Second, converter and controller designs are disclosed as an overview and third, the proposed circuit and its results obtained in MATLAB-Simulink platform are investigated. Finally, the experimental setup and the results obtained are discussed. In this paper chapter II describe the proposed system modelling and analysis. Chapter III delineate the simulation circuits and results of five level, eleven level $\mathrm{H}$ Bridge and $\mathrm{T}$ bridge inverter. Chapter IV explains about hardware implementation of the project and THD compared with T bridge inverter. Finally, it is concluded in Chapter IV.

\section{PROPOSED SYSTEM MODELLING AND ANALYSIS}

Figure 1 represents the block diagram of the conventional Z-source converter system. It has unique impedance in X shape which uses 4 passive elements. All the ways of power conversions between power sources and the main circuit can be performed effectively [14]. However, the major drawback is having low average power conversion rate and total harmonic distortion (THD) under lower boosting ratio range $[15,16]$.

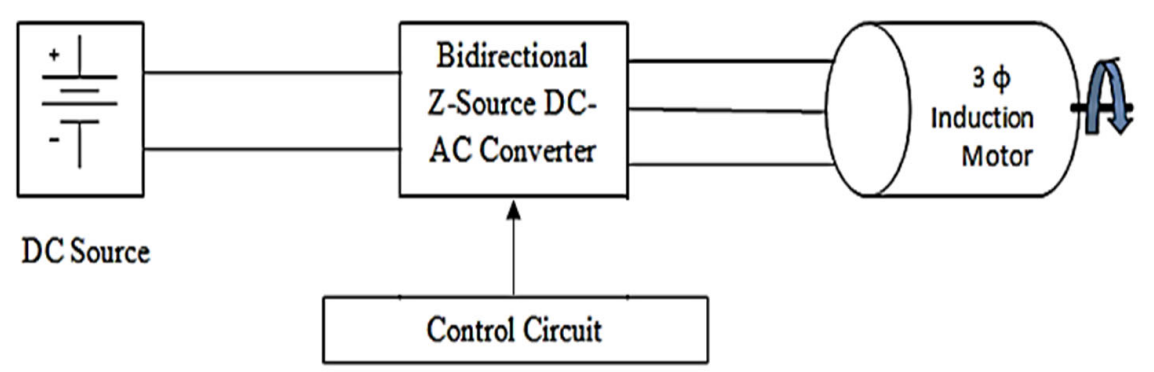

Figure 1. Schematic representation of the existing system

This can be effectively overcome by the projected system. The schematic representation of the existing system is depicted in Figure 2. The simulations of both the systems are performed. Z-source DC-DC converter system configure ration is compared with non-isolated DC-DC power converter with high gain in voltage system based on the voltage boost up, power handling capacity and THD. This paper deals with the step-up mode alone since the analysis is meant for EV application battery to drive operation [17]. The future analysis is planned for step down mode also.

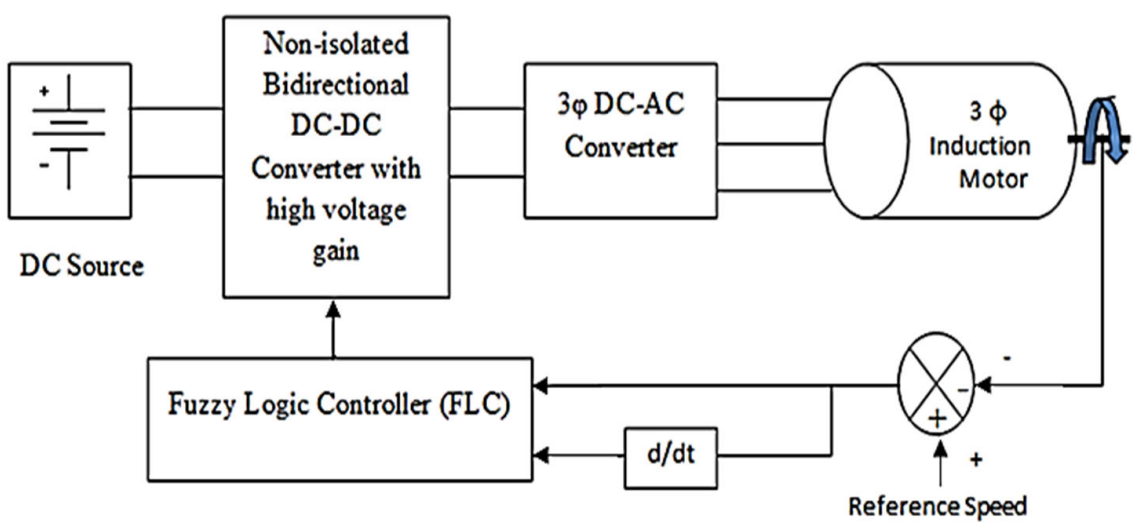

Figure 2. Block diagram of the proposed system

Figure 3 depicts the schematic circuit diagram of the proposed converter [13]. Power switches are $\mathrm{S} 1$ and S2 whereas S3 and S4 act as active rectifiers [18]. At first, S1 and S2 power switches are turned on. 
During this mode, inductor L1 gets magnetized by the capacitor's C stored charges and low voltage dc source

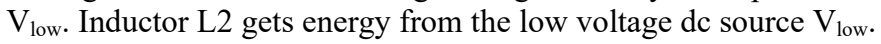

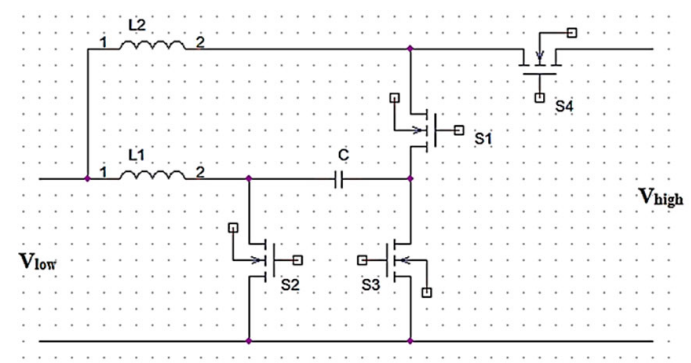

Figure 3. Schematic circuit of the proposed system

The voltages along inductors $\mathrm{L}_{1}$ and $\mathrm{L}_{2}$ are indicated below.

$$
\begin{aligned}
& V_{\text {L1ind }}=V_{\text {low }}+V_{\text {cap }} \\
& V_{\text {L2ind }}=V_{\text {low }} \\
& {\left[\begin{array}{l}
V_{\text {L1ind }} \\
V_{\text {L2ind }}
\end{array}\right]=\left[\begin{array}{ll}
1 & 0 \\
0 & 0
\end{array}\right]\left[\begin{array}{c}
V_{\text {cap }} \\
V_{\text {high }}
\end{array}\right]+\left[\begin{array}{l}
1 \\
1
\end{array}\right]\left[V_{\text {low }}\right]}
\end{aligned}
$$

In the next mode, $S_{3}$ and $S_{4}$ switches must be turned on whereas the other switches $S_{1}$ and $S_{2}$ are made off. The stored energy of $L_{1}$ inductor and low voltage input $\mathrm{V}_{\text {low }}$ is used to offer high voltage output. Also, the stored energy of $\mathrm{L}_{2}$ inductor and low voltage input $\mathrm{V}_{\text {low }}$ is used to charge $\mathrm{C}$ capacitor [19]. The inductor $\mathrm{L}_{1}$ and $\mathrm{L}_{2}$ voltages obtained this mode are given below.

$$
\begin{aligned}
& V_{\text {L1ind }}=V_{\text {low }}-V_{\text {high }} \\
& V_{\text {L2ind }}=V_{\text {low }}-V_{\text {cap }} \\
& {\left[\begin{array}{l}
V_{\text {L1ind }} \\
V_{\text {L2ind }}
\end{array}\right]=\left[\begin{array}{cc}
0 & -1 \\
-1 & 0
\end{array}\right]\left[\begin{array}{c}
V_{\text {cap }} \\
V_{\text {high }}
\end{array}\right]+\left[\begin{array}{l}
1 \\
1
\end{array}\right]\left[V_{\text {low }}\right]} \\
& \text { Here, }\left[A_{1}\right]=\left[\begin{array}{cc}
1 & 0 \\
0 & 0
\end{array}\right] \text { and }\left[B_{1}\right]=\left[\begin{array}{l}
1 \\
1
\end{array}\right] \\
& {\left[A_{2}\right]=\left[\begin{array}{cc}
0 & -1 \\
-1 & 0
\end{array}\right] \text { and }\left[B_{2}\right]=\left[\begin{array}{l}
1 \\
1
\end{array}\right]} \\
& {[A]=\propto A_{1}+(1-\propto) A_{2}} \\
& {[A]=\left[\begin{array}{cc}
D & -(1-D) \\
-(1-D) & 0
\end{array}\right]} \\
& {[B]=\propto B_{1}+(1-\propto) B_{2}} \\
& {[B]=\left[\begin{array}{c}
1 \\
1
\end{array}\right]} \\
& {\left[V_{\text {out }}\right]=\left[\begin{array}{ll}
0 & 1
\end{array}\right]\left[\begin{array}{l}
V_{\text {cap }} \\
V_{\text {high }}
\end{array}\right]+[0]\left[V_{\text {low }}\right]}
\end{aligned}
$$

Here $\mathrm{V}_{\text {low }}$ and $\mathrm{V}_{\text {high }}$ be the input and output voltage after stepping up, $\mathrm{V}_{\text {lind }}$ and $\mathrm{V}_{\text {2ind }}$ are the voltage measured along the inductors. $V_{\text {cap }}$ is the voltage across the capacitor, $\alpha$ be duty ratio and then $R_{M}$ be the load 
resistance. By using volt-sec principle of balancing for (3) and (6), voltage gain during stepping up mode is as presented below,

$$
\frac{V_{\text {high }}}{V_{\text {low }}}=\left(\frac{1}{1-\alpha}\right)^{2}
$$

The design equations for finding the values of the inductors are given as [20].

$$
\begin{aligned}
& L_{1 \text { ind }}=\frac{\propto(2-\propto)(1-\propto)^{2} R_{M}}{2 f_{S w}} \\
& L_{2 \text { ind }}=\frac{(1-\propto)^{4} R_{M}}{2 f_{S w}}
\end{aligned}
$$

\section{SIMULATION RESULTS AND DISCUSSIONS}

Simulation results of existing and proposed system are presented in Table I. The comparison indicates that the proposed system produces higher output power with reduced THD [21]. Open loop BDDPCS model with varying load is as depicted in Figure 4. The simulation parameters are given in Appendix A.

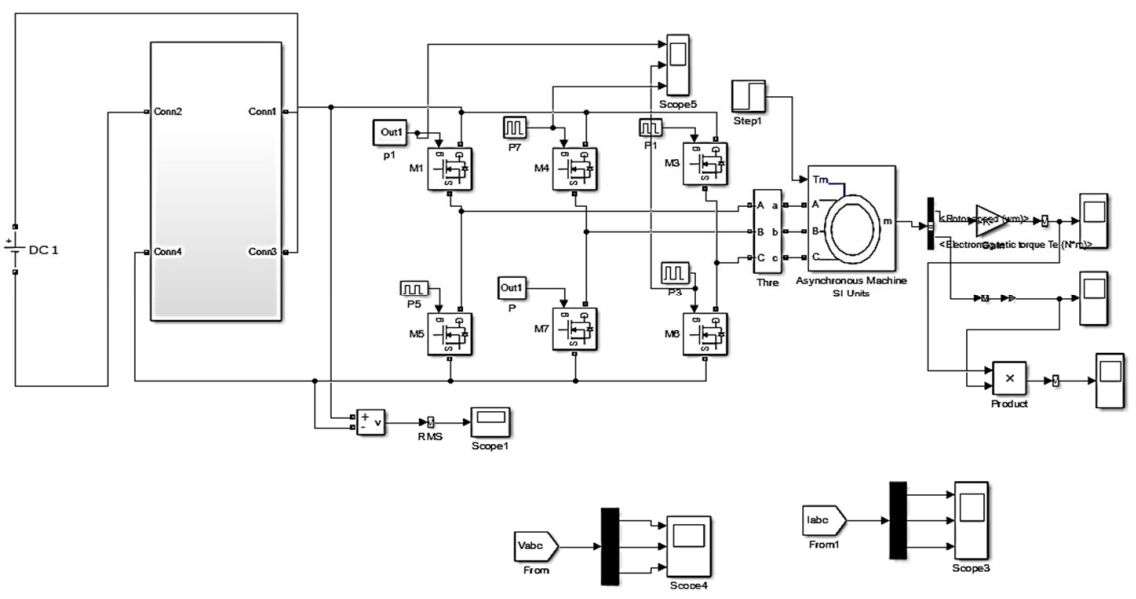

Figure 4. Open loop BDDPCS system with varying load

Table 1. Comparison of output voltage, power for existing and proposed system

\begin{tabular}{ccccc}
\hline Converter System & Vin & Vo & Output current THD & Output Power \\
\hline Existing & $100 \mathrm{~V}$ & $360 \mathrm{~V}$ & $15.07 \%$ & $2700 \mathrm{~W}$ \\
Proposed & $100 \mathrm{~V}$ & $400 \mathrm{~V}$ & $9.95 \%$ & $3700 \mathrm{~W}$ \\
\hline
\end{tabular}

A design of PI, FOPID and fuzzy controller were performed for the boost operation of the proposed converter to improve the system's transient characteristics. Linear control technologies use a small signal design transfer function whereas FLC uses human being's intuitive decisions. Closed loop system with PIC. $\mathrm{s}(\mathrm{n})$ (actual speed) of BDDCIS drive is identified and then compared with sref (set speed) to obtain e(n) (speed error) $[22,23]$. This is given to the PIC and the corresponding output form the controller is forwarded to comparator.

The updated gate pulse from the comparator is used to trigger the control switches in converter. This in turn helps in regulating the voltage and speed of the drive. The motor speed reduces from 1350 RPM to 1294.7 RPM and the Torque settles at 4 N-m. In the conventional PID controller, the derivative as well as integrator order is 1 where as in dynamical system called FOPID, there exists a degree of freedom in the derivative and integrator order as shown in equation (15). Also, the efficiency is far better than conventional mode. It was first proposed by Podlubny in the year 1999 [24]. 


$$
u(s)=\left[K_{p}+\frac{K_{i}}{s^{n}}+K_{d} s^{m}\right] e(s)
$$

Where $\mathrm{u}(\mathrm{s})=$ Control signal

$\mathrm{e}(\mathrm{s})=$ Error signal

The closed loop model of FOPIDC is analyzed next. The PI Controller is replaced by FOPID controller. The motor speed is 1300 RPM and the torque developed is is $4 \mathrm{~N}-\mathrm{m}$. Rise time is reduced from 0.6 to $0.45 \mathrm{sec}$. Settling time is decreased from 2.3 to $1.4 \mathrm{sec}$. The peak time changes from 0.51 to 0.53 second and error is minimized from 5.3 to $2.8 \mathrm{~V}$. No mathematical modelling is necessary for FLC. It can utilize the general known knowledge of the plant. Fuzzification (crisp to fuzzy), linguistic descriptive rules, inference mechanism (for choosing the correct rule for a current plant situation) and defuzzification (fuzzy to crisp) are the major four components in FLC [25]. There are two specific inputs fed to the fuzzy controller. Error in motor RPM (e(n)) is the first input given in (16) and successive error difference (ce(n)) is the second input given in (17). Fuzzy controller output is change in duty cycle.

$$
\begin{aligned}
& e(n)=s_{r e f}-s(n) \\
& c e(n)=e(n)-e(n-1)
\end{aligned}
$$

$S_{\text {ref }}-$ Reference speed

$\mathrm{s}(\mathrm{n})$ - motor speed at nth sample.

e(n-1) - error at (n-1) sample

Closed loop model with FLC is as depicted in Figure 5. The Input variable $1 \& 2$ are illustrated in Figure 6 and 7 respectively. Figure 8 denotes the output variable. The Fuzzy Rules are summarized Table 2. The motor speed value is $1300 \mathrm{RPM}$. The Torque response is $4 \mathrm{~N}-\mathrm{m}$. The time domain variables are compared for different controller implementation is shown in Table 3. The settling time is decreased from 2.3 to 0.6 seconds. Error is minimized from 5.3 to 0.08 RPM.

The Figure 9 shows the normalized torque, speed and power obtained for different controllers' implementation. The blue curve indicates open loop system. Orange and green curves represent PI and FOPID controlled system respectively. Finally, the red curves represent the FLC based system designed. The inverter output current is shown in Figure 10 for different controller implementation.

Table 2. Rule Table

\begin{tabular}{cccccccc}
\hline e/ce & NL & NM & NS & ZE & PS & PM & PL \\
\hline NL & NL & NL & NL & NL & NM & NS & ZE \\
NM & NL & NL & NL & NM & NS & ZE & PS \\
NS & NL & NL & NM & NS & ZE & PS & PM \\
ZE & NL & NM & NS & ZE & PS & PM & PL \\
PS & NM & NS & ZE & PS & PM & PL & PL \\
PM & NS & ZE & PS & PM & PL & PL & PL \\
PL & ZE & PS & PM & PL & PL & PL & PL \\
\hline
\end{tabular}

Int J Pow Elec \& Dri Syst, Vol. 11, No. 2, June 2020 : $594-604$ 


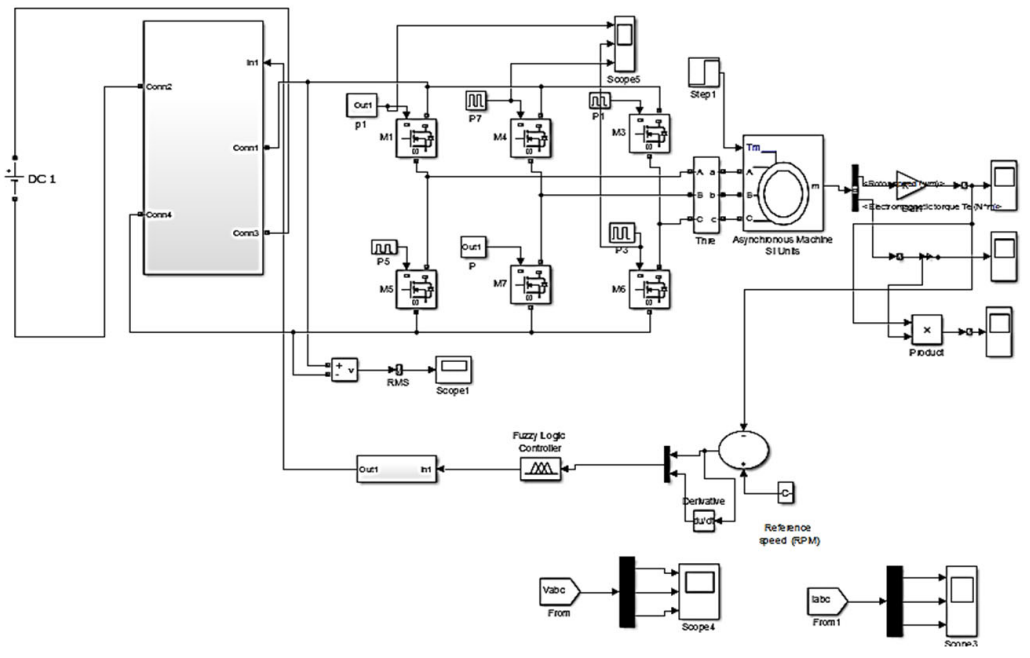

Figure 5. Closed loop BDDIC system with FL

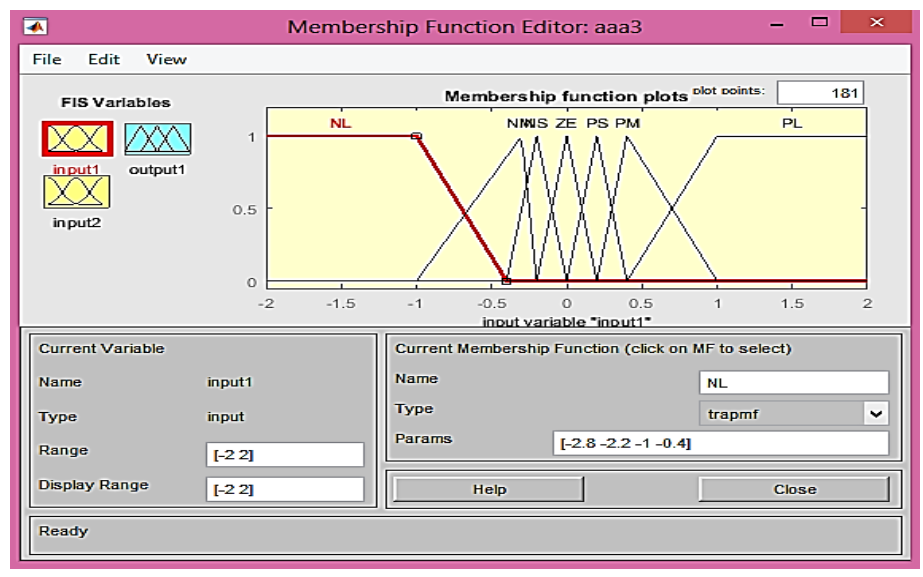

Figure 6. Input variable 1

Table 3. Comparison of time domain parameters with pi, fopid \& fl controller

\begin{tabular}{ccccc}
\hline Controller & $T r$ & $T s$ & $T p$ & Ess \\
\hline PI & 0.60 & 2.3 & 0.51 & 5.3 \\
FOPID & 0.35 & 1.4 & 0.43 & 2.8 \\
FLC & 0.3 & 0.6 & 0.46 & 0.08 \\
\hline
\end{tabular}




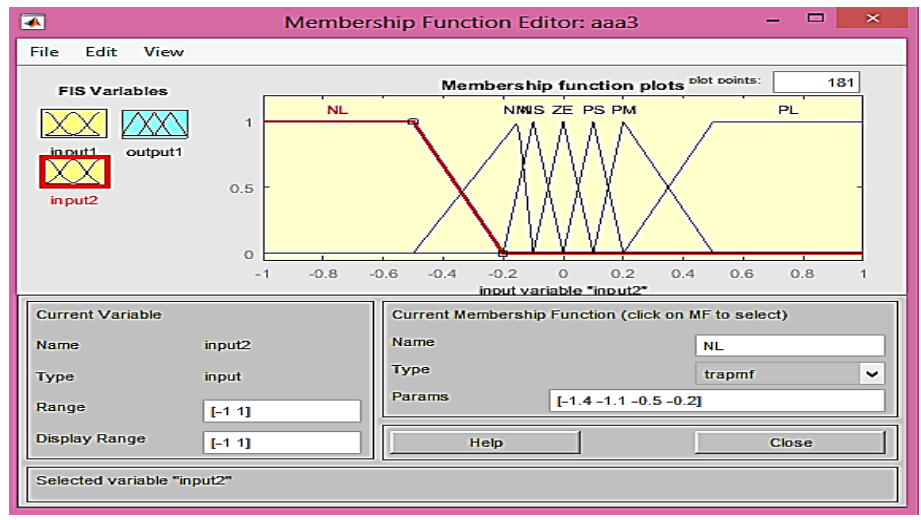

Figure 7. Input variable 2

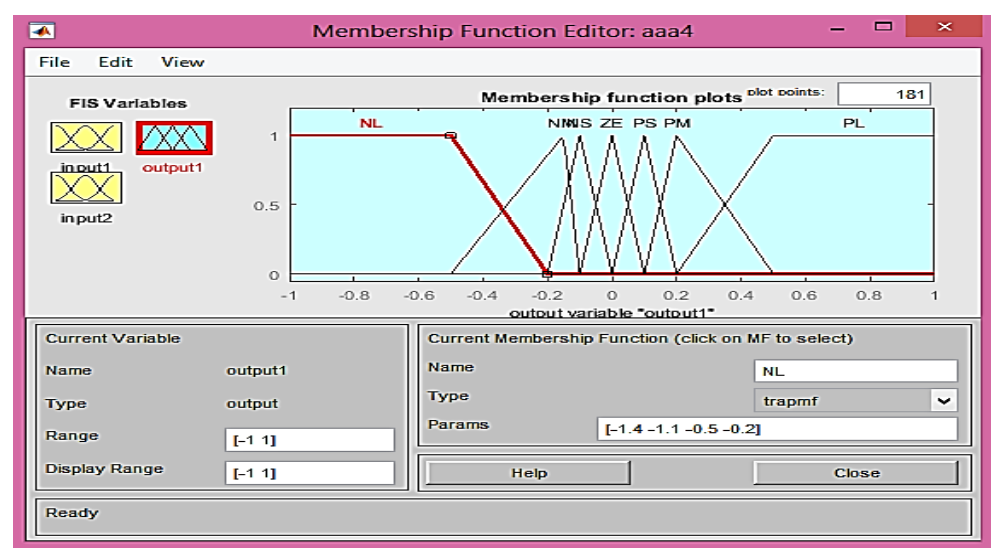

Figure 8. Output variable
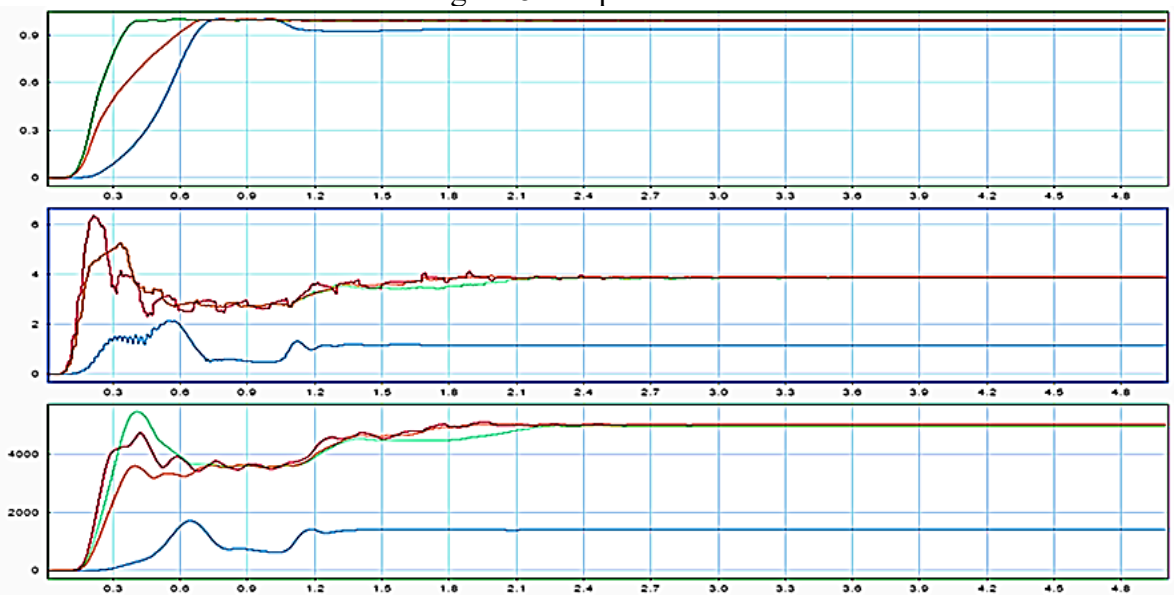

Figure 9. Motor characteristics torque, speed and power 

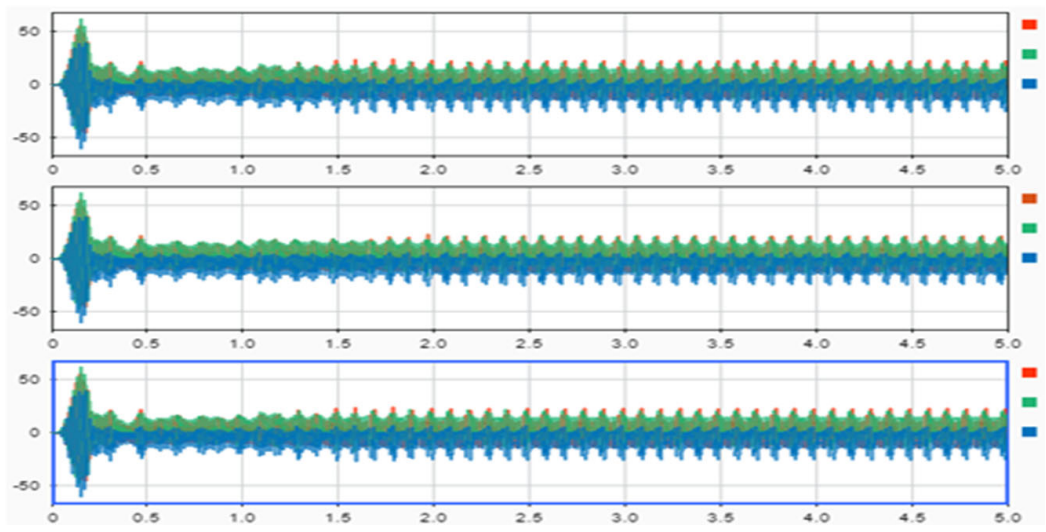

Figure 10. Inverter output current for FLC, FOPID and PI controlled system

\section{EXPERIMENTAL RESULTS}

The functionality of the proposed converter is verified experimentally with the design parameters as given in Table 4. The voltage profile used in the simulation is scaled down by 4 for the experimental verification. The hardware setup includes the proposed bidirectional converter, three phase three level inverter and three phases, $0.5 \mathrm{HP}, 400 \mathrm{~V}$ induction motor.

LV side of bidirectional converter is supplied by $24 \mathrm{~V}$ DC supply which is boosted to $80 \mathrm{~V}$ DC on the $\mathrm{HV}$ side. A three-phase induction motor is connected as load on the HV side via inverter. Figure 11 depicts the prototype setup of the proposed BDDCIS. The PIC micro controller PIC16F84A is used to offer the firing pulses to the power converter used in the setup. The input supply voltage considered to test the hardware is $24 \mathrm{~V}$ as shown in Figure 12.

Table 4. The design parameters of the experiment

\begin{tabular}{lclc}
\hline \multicolumn{3}{l}{ Simulation components specifications } & \multicolumn{2}{l}{ hardware components specifications } \\
\hline $\mathrm{V}_{\text {in }}$ & $100 \mathrm{~V}$ & $\mathrm{~V}_{\text {in }}$ & $24 \mathrm{~V}$ \\
$\mathrm{~L}_{1}, \mathrm{~L}_{2}$ & $10 \mathrm{mH}$ & $\mathrm{L}_{1}, \mathrm{~L}_{2}$ & $2.5 \mathrm{mH}$ \\
$\mathrm{L}_{3}$ & $200 \mathrm{mH}$ & $\mathrm{L}_{3}$ & $2 \mathrm{mH}$ \\
$\mathrm{C}_{1}$ & $64 \mu \mathrm{F}$ & $\mathrm{C}_{1}$ & $2200 \mu \mathrm{F}$ \\
$\mathrm{C}_{2}, \mathrm{C}_{3}$ & $1200 \mu \mathrm{F}$ & $\mathrm{C}_{2}, \mathrm{C}_{3}$ & $2200 \mu \mathrm{F}$ \\
MOSFET(IRF840) & $500 \mathrm{~V} / 8 \mathrm{~A}$ & $\mathrm{MOSFET}$ & $500 \mathrm{~V} / 8 \mathrm{~A}$ \\
Diode & $230 \mathrm{~V} / 1 \mathrm{~A}$ & Diode & $230 \mathrm{~V} / 1 \mathrm{~A}$ \\
& & $\mathrm{~V}_{0}$ & $80 \mathrm{~V}$
\end{tabular}

Figure 13 depicts gating pulses for the switch (MOSFET (IRF840) the BDDCI system. Input voltage of $24 \mathrm{~V}$ is boosted to $80 \mathrm{~V}$ output. The experimental output voltage is shown in +14 . DC/DC converter is connected to three phase inverters. The switching gate pulses for the power switches in inverter and the output voltage obtained in inverter are as shown in Figure 16 and 17 respectively. 


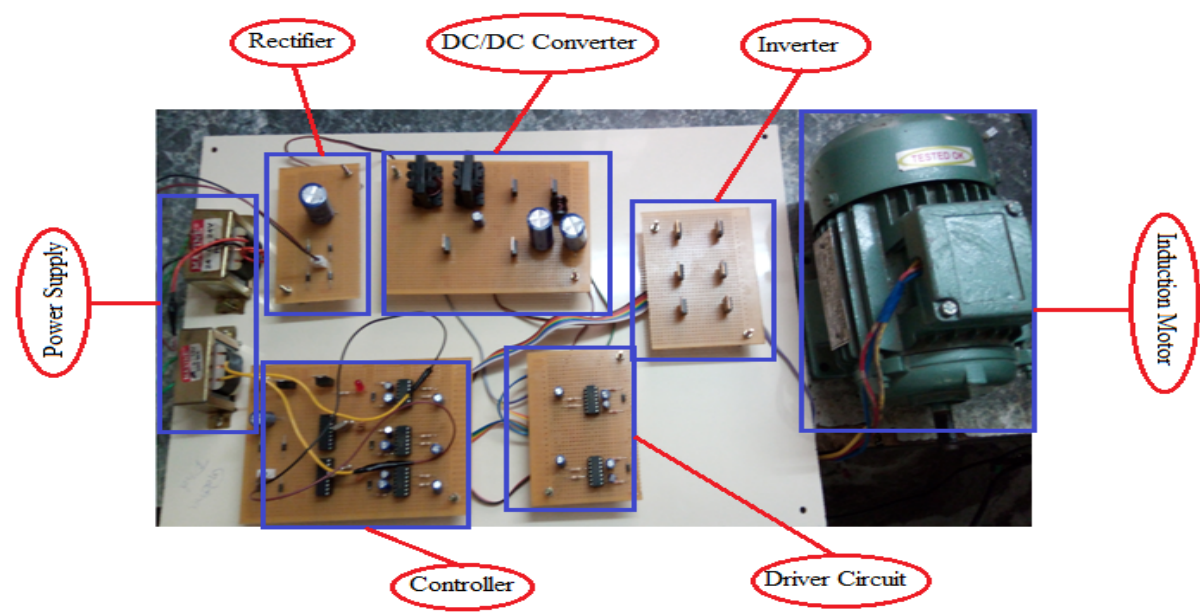

Figure 11. Test Bench for BDDIS

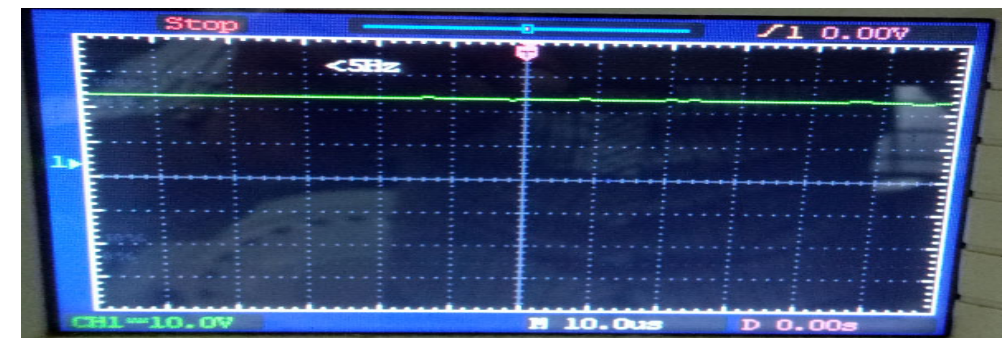

Figure 12. Input voltage

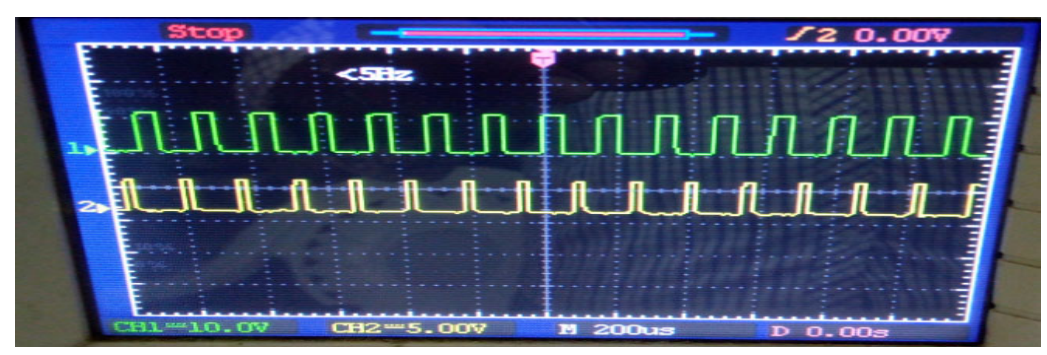

Figure 13. Switching pulse for S1 \& S2 of high gain converter

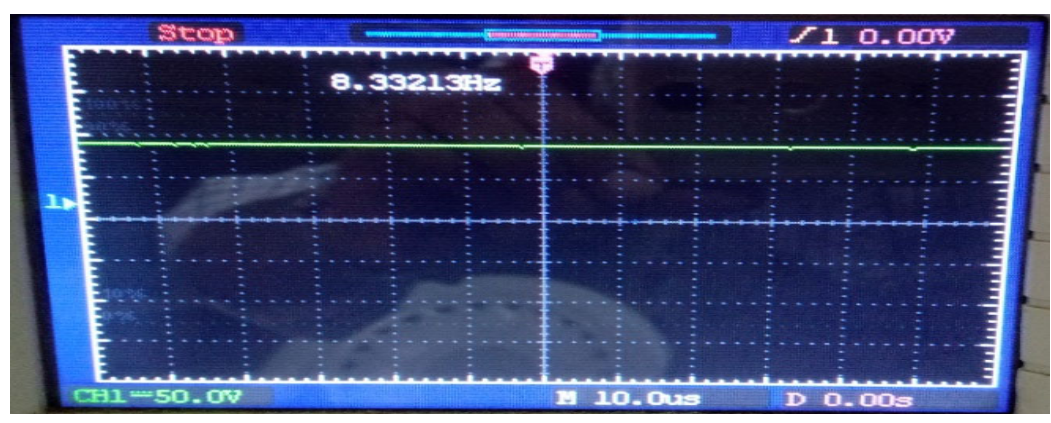

Figure 14. Output voltage of high gain converter 


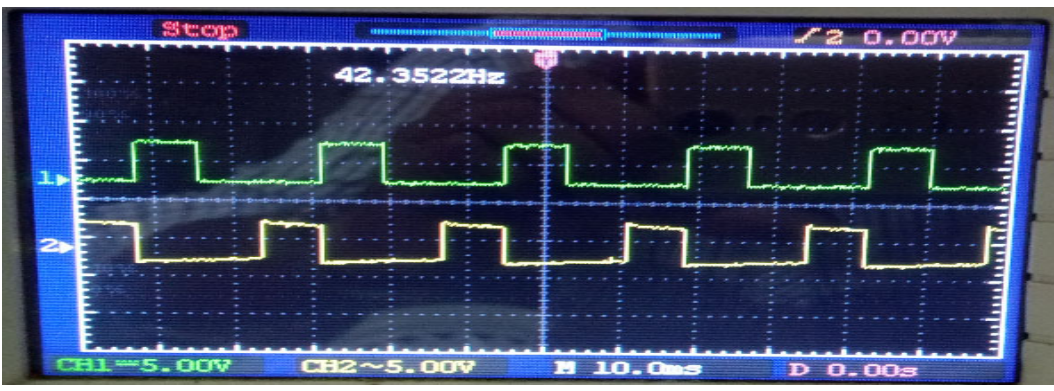

Figure 15. Switching pulses for three phase Inverter

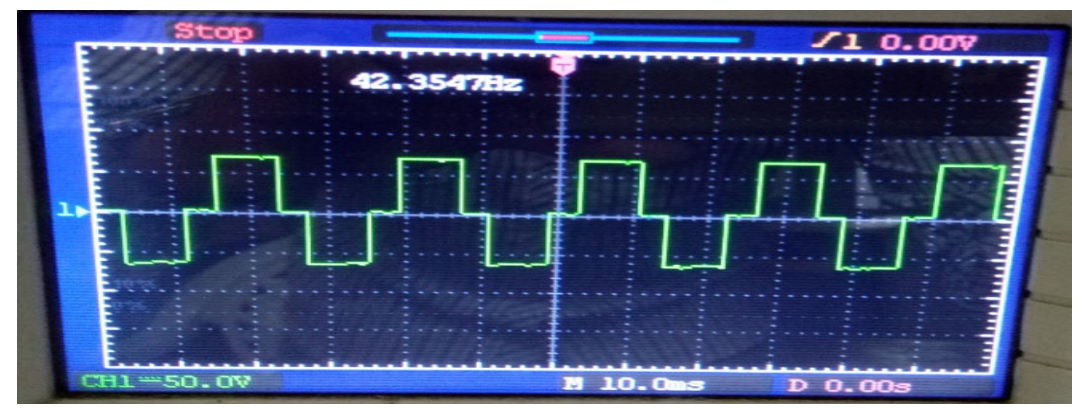

Figure. 16. Output voltage of three phase inverter

\section{CONCLUSION}

The design, model and analysis of the BDDPCS has been carried out. The output waveforms of BDDPCS are compared to the bidirectional DC/DC power converter system. The characteristics of BDDPCS are obtained to be better than the conventional converter. The BDDPCS is examined using a step input for load torque. BDDPCS under the closed loop condition with PIC and FLC are also explored. Settling time for FLC is decreased to $0.56 \mathrm{sec}$ and error is minimized to $0.08 \mathrm{RPM}$. Hence, FLC based BDDPCS is better than PIC based system. The experiment result validates the software results.

\section{REFERENCES}

[1] Jesus E. Valdez-Recendez, Abraham Claudio-Sanchez, Gerardo V. Guerrero-Ramirez, Carlos Aguilar-Castillo, Alejandro Tapia-Hernandez, Josefa Gordillo-Estrada, "Interleaved High-Gain Boost Converter with Low InputCurrent Ripple For Fuel Cell Electric Vehicle Applications," Proceeding of International Conference on Connected Vehicles and Expo (ICCVE), Las Vegas, USA, pp. 812-817, 2-6 Dec 2013.

[2] M. Jang and V. G. Agelidis, "A minimum power-processing-stage fuel -cell energy system based on a boostinverter with a bidirectional backup battery storage," IEEE Trans. Power Electronics, vol. 26, no. 5, pp. 1568 1577, May 2011.

[3] Yi-Ping Hsieh, Jiann-Fuh Chen, Lung-Sheng Yang, Chang-Ying Wu, Wei-Shih Liu, "High-Conversion-Ratio Bidirectional DC-DC Converter with Coupled Inductor," IEEE Transactions on Industrial Electronics, vol. 61, no. 1, pp. 210-222, Jan 2014.

[4] Prakash G and Subramani C, "Space Vector and Sinusoidal Pulse Width Modulation of Quasi Z-Source Inverter for Photovoltaic System," International Journal of Power Electronics and Drive Systems (IJPEDS), vol. 7, no. 3, pp. 601-609, 2016.

[5] T. F. Wu, Y. C. Chen, J. G. Yang, C. L. kuo, "Isolated bidirectional full-bridge dc-de converter with a fly back snubber,” IEEE Trans. Power Electronics, vol. 25, no. 7, pp. 1915-1922, Jul 2010.

[6] G. Ma, W. Qu, G. Yu, Y. Liu, N. Liang, W. Li, "A zero-voltages witching bidirectional dc-de converter with state analysis and soft switching- oriented design consideration," IEEE Trans. Industrial Electronics, vol. 56, no. 6, pp. 2174-2184, Jun 2009.

[7] A. K. Rathore, U. R. Prasanna, "Analysis, design, and experimental results of novel snubber less bidirectional naturally clamped ZCS/ZVS current-fed half-bridge DC/DC converter for fuel cell vehicles," IEEE Trans Industrial Electronic, vol. 60, no.10, pp. 4482-4491, Oct 2013. 
[8] P. Xuewei, A. K. Rathore, "Novel bidirectional snubber less naturally commutated soft-switching current-fed fullbridge isolated DC/DC converter for fuel cell vehicles," IEEE Trans. Industrial Electronics, vol. 61, no. 5, pp. 2307-2315, May 2014.

[9] Y. S. Lee, Y.Y. Chiu, "Zero-current-switching switched-capacitor bidirectional dc-dc converter," Proceeding of IET Electric Power Applications, vol. 152, no. 6, pp. 1525-1530, Nov 2005.

[10] A. Ajami, H. Ardi, A. Farakhor, "A novel high step-up DC/DC converter based on integrating coupled inductor and switched-capacitor techniques for renewable energy applications," IEEE Trans. Power Electronics, Vol. 30, No. 8, pp. 4255 - 4263, Aug 2015.

[11] Prakash, G, C. Subramani, "A Low-Cost Single-Phase Grid Connected Reduced Switch PV Inverter based on Time Frame Switching Scheme,” International Journal of Electrical Power and Energy Systems, Elsevier, vol. 77, no. 1, pp. 100-111, 2016.

[12] R. Y. Duan, J. D. Lee, "High-efficiency bidirectional DC-DC converter with coupled inductor," IET Power Electron, vol. 5, no. 1, pp. 115-123, Jan 2012.

[13] Usha S and Subramani C, "Performance Analysis of H-bridge and T-Bridge Multilevel Inverters for Harmonics Reduction,” International Journal of Power Electronics and Drive Systems, vol. 9, no. 1, pp. 231-239, 2018.

[14] HosseinArdi, Ali Ajami, FaezehKardan, Shahla Nikpour Avilagh, "Analysis and Implementation of a Nonisolated Bidirectional DC-DC Converter with High Voltage Gain,” IEEE Trans. on Industrial Electronics, vol. 63, no. 8, pp. 4878-4888, Aug 2016.

[15] K. Dhineshkumar and C. Subramani, "Kalman Filter Algorithm for Mitigation of Power System," International Journal of Electrical and Computer Engineering (IJECE), vol. 8, no. 2, pp. 771-779, 2018.

[16] Muhammad Ali Raza Anjum, "A New Approach to Adaptive Signal Processing”, Indonesian Journal of Electrical Engineering and Informatics, vol. 3, no. 2, pp. 93-108, 2015.

[17] Sengamalai U, Chinnamuthu S, "An experimental fault analysis and speed control of an induction motor using motor solver," J. Electr. Eng. Technol, vol. 12, pp. 761-768, 2017.

[18] Subotic I, Bodo N, Levi E., "Single-phase on-board integrated battery chargers for EVs based on quinary phase machines," IEEE Trans. Power Electron, vol. 31, pp. 6511-6522, 2016.

[19] Krithika V and Subramani C, "A comprehensive review on choice of hybrid vehicles and power converters, control strategies for hybrid electric vehicles," Int J Energy Res, vol. 42, pp. 1789-1812, 2018.

[20] Geetha A and Subramani C, "A comprehensive review on energy management strategies of hybrid energy storage system for electric vehicles," Int J Energy Res, vol. 41, pp. 1817-1835, 2017.

[21] Iro Z S, Subramani C and Dash S, “A brief review on electrode materials for supercapacitor," Int. J. Electrochem. Sci, vol. 11, pp. 10628-10643, 2016.

[22] Charles I kechukwu OdehEmeka S. Obe, Olorunfemi Ojo, "Topology for Cascaded Multilevel Inverter," IET Power Electron, vol. 5, no. 4, pp. 1-9, 2016.

[23] Sasan Hashemizadeh Ashan and Mohammad Monfared, "Design and Comparison of Nine-Level Single-phase Inverter with a Pair of Coupled Inductors and Two DC Sources," IET Power Electronics, vol. 9, no. 11, pp. 22712281, 2016.

[24] R. Seyezhai and B.L. Mathur "Analysis, Design and Experimentation of Interleaved Boost Converter for Fuel Cell Power Source," International Journal of Research and Reviews in Information Sciences, vol. 1, no. 2, pp. 20466439, June 2011

[25] J. Srinivas Rao, P. Srinivasa Varma, T. Suresh Kumar, "Novel Switching Design Structure for Three Phase 21Level Multilevel Inverter Fed BLDC Drive Application," International Journal of Power Electronics and Drive System (IJPEDS), vol. 9, no. 3, pp. 1202-1213, 2018.

Int J Pow Elec \& Dri Syst, Vol. 11, No. 2, June 2020 : $594-604$ 